\title{
The effect of Rituximab treatment on T cells
}

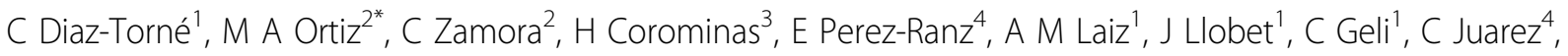 \\ C Diaz $^{1}$, S Vidal $^{2}$
}

From 5th European Workshop on Immune-Mediated Inflammatory Diseases

Sitges-Barcelona, Spain. 1-3 December 2010

\section{Introduction}

Rituximab is a therapeutic anti-CD20 antibody used for in vivo depletion of B cells.

However, the mechanisms of action are not fully understood because clinical responses do not always correlate with the extent and duration of $\mathrm{B}$ cell depletion.

\section{Aim}

This study was conducted to examine the effect of B cell depletion on peripheral $\mathrm{T}$ cells from rheumatoid arthritis patients.

\section{Methods}

RA patients received rituximab (1000 mg). Peripheral blood samples were collected at baseline and at 30, 90 and 180 days postinfusion. The phenotype of $\mathrm{T}$ cell subsets of peripheral blood from RA patients were examined by cytometry and cytokine production was determined by ELISA.

\section{Results}

According to our previous results, peripheral B cell depletion was fully effective by 30 days. No changes in the percentage of CD3+, CD4+, CD8+ and NK cells were found. There was a comparative progressive diminution of CD8 + CD45RO+ cells with recovery starting at 180 days. DAS28 significantly correlated with CD8+CD45RO+ cells. Since CD8+CD45RO+ diminution was coincident with the clinical response measured as DAS28, we investigated whether IL-15 could be responsible for this population changes in rheumatoid arthritis patients. As expected there was significant levels of IL-15 in the serum RA patients $(110 \pm 31 \mathrm{pg} / \mathrm{ml})$ compared to healthy donors $(<10 \mathrm{pg} / \mathrm{ml})$. Rituximab treatment decreased IL-15 levels in serum from rheumatoid arthritis patients. Although, no significant correlation was observed between IL-15 in the

\footnotetext{
${ }^{2}$ Dep. Immunologia, Institut Rec. Hospital S. Creu i S. Pau, Barcelona, Spain
} Full list of author information is available at the end of the article serum and CD8+CD45RO+ cells, levels of IL-15 transpresented on the surface of neutrophils from RA patients significantly correlated with $\mathrm{CD} 8+\mathrm{CD} 45 \mathrm{RO}+(\mathrm{p}<0.01)$ cells and CD8+CD45RO+/RA+ ratio $(\mathrm{p}<0.001)$.

\section{Conclusion}

This study demonstrates that rituximab treatment is able to reduce IL-15 levels. This reduction could be responsible for tthe CD45RO+ changes during the follow-up.

\section{Author details \\ ${ }^{1}$ Servei Reumatologia, Hospital S. Creu i S. Pau, Barcelona, Spain. ${ }^{2}$ Dep. Immunologia, Institut Rec. Hospital S. Creu i S. Pau, Barcelona, Spain. ${ }^{3}$ Serve Reumatologia, Hospital Dos de Maig, Barcelona, Spain. ${ }^{4}$ Dep. Immunologia, Hospital S. Creu i S. Pau, Barcelona, Spain.}

Published: 25 November 2010

doi:10.1186/1479-5876-8-S1-P66

Cite this article as: Diaz-Torné et al:: The effect of Rituximab treatment on T cells. Journal of Translational Medicine 2010 8(Suppl 1):P66.

Submit your next manuscript to BioMed Central and take full advantage of:

- Convenient online submission

- Thorough peer review

- No space constraints or color figure charges

- Immediate publication on acceptance

- Inclusion in PubMed, CAS, Scopus and Google Scholar

- Research which is freely available for redistribution 